LAERE MIDDEL ODK

\title{
Brugerinddragelse i brug og integration af læringsplatforme
}

Af Lone Dirckinck-Holmfeld, Aalborg Universitet

Korrekt citering af denne artikel efter APA-systemet (American Psychological Association System, 6th Edition): Dirckinck-Holmfeld, L. (2019). Brugerinddragelse i brug og integration af læringsplatforme. Learning Tech - Tidsskrift for læremidler, didaktik og teknologi, (6), 106-133. DOI 10.7146/lt.v4i6.110915 


\section{Abstract}

Artiklen undersøger, hvordan kombinationen af deltagende design og en ekspansiv læringstilgang kan guide processen med at integrere læringsplatformene i danske skoler. Hvordan er det muligt at etablere lokalt ejerskab, hvordan er det muligt at styrke de faglige og pædagogiske handlinger, og hvordan er det muligt at udvikle nye læringskulturer rammesat og støttet af de nye platforme? Denne artikel skriver sig ind i det videnskabsfelt, som omhandler "ibrugtagning" af teknologi, særligt den gren som udvikler begreber om forandring og transformation af professionel arbejdspraksis. Artiklen fokuserer særligt på at undersøge, hvorledes fremtidsværkstedet som metode og designworkshops kan skabe indsigt i samt udvikle det pædagogiske personales engagement og ejerskab i forhold til en faglig, pædagogisk og organisatorisk brug af læringsplatforme.

The article examines how the combination of participatory design and an expansive learning approach can guide the process of integrating learning platforms in Danish schools. How to establish local ownership, how to strengthen the professional and pedagogical actions, and how to develop new learning cultures mediated and supported by the new platforms? This chapter forms part of the field of research that deals with deployment and appropriation of technology, especially the branch that develops concepts of change and transformation of professional work practices. The chapter focuses on examining how the combination of future workshops as a method with design workshops provides insights into and develop the educational staff's commitment and ownership in relation to a professional, pedagogical and organizational use of learning platforms. 


\section{Brugerinddragelse i brug og integration af læringsplatforme}

\section{Indledning}

I 2014, aftalte regeringen og Kommunernes Landsforening at realisere initiativet om en brugerportal for folkeskolen. Aftalen udsprang af folkeskolereformen (vedtaget 2013) og har til formål at understøtte folkeskolereformen ved hjælp af konkrete digitale initiativer. Som beskrevet i brugerportalsinitiativet (KL, 2016) indebærer initiativet, at alle kommuner frem mod udgangen af 2017 skal anskaffe to digitale løsninger til skolerne: En samarbejdsplatform og en læringsplatform. Formålet er "at understøtte folkeskolereformen og bringe den digitale folkeskole et stort skridt fremad ved at etablere tidssvarende digitale løsninger" (KL, 2016, s. 11). Løsningerne skal kunne understøtte kommunikation, læring og trivsel i folkeskolen og bidrage til opfyldelse af målene i folkeskolereformen.

Som følge af dette lovbestemte arbejde har alle kommuner indkøbt en læringsplatform. Læringsplatformen skulle være indkøbt ultimo 2017, medens samarbejdsplatformen forventes implementeret i løbet af 2019.

I 2016 blev forskningsprojektet "Anvendelse af digitale læringsplatforme og læremidler" (Misfeldt, 2016), herefter blot omtalt som Læringsplatformsprojektet, igangsat. Projektet var fase 2 af et samlet initiativ i regi af den fællesoffentlige indsats "It i folkeskolen". Hvor fase 1 var en undersøgelse foretaget af EVA i foråret 2016, der kortlagde landets skolers første erfaringer med implementering af læringsplatformene, undersøgte Læringsplatformsprojektet et udsnit af landets skolers anvendelse af læringsplatforme ud fra henholdsvis et pædagogisk/didaktisk, teknologisk og organisatorisk fokus.

Projektets forventning var at skabe generaliserbar og aktiverbar viden om, hvordan læringsplatforme potentielt og reelt understøtter og påvirker det pædagogiske personales arbejde, elevens læring samt samarbejdet med forældrene. I projektet er 
udviklet indsatser lokalt på de deltagende skoler, der understøtter implementering af læringsplatforme i den danske folkeskole. Samtidig undersøges disse platformes betydning for den pædagogiske og didaktiske praksis samt for elevernes læring (Misfeldt, 2016).

Som dokumenteret i den opsamlende rapport fra Læringsplatformsprojektet (Svensson, Tamborg, Misfeldt, Qvortrup, Kølsen \& Gynther, 2017) arbejder skolerne i forskellige tempi i forhold til at implementere læringsplatformen. Nogle skoler har arbejdet med den i flere år, medens andre skoler lige er begyndt. I alle tilfælde rejser dette storskala Læringsplatformsprojekt spørgsmål om, hvordan en ny læringsplatform tages i brug på skolerne og hvilke metoder, som kan understøtte implementering og ibrugtagning.

I denne artikel lægges særligt vægt på at udvikle en metode for "ibrugtagning" af læringsplatforme, som er tilpasset til skolekulturen og lærernes måde at arbejde på. Artiklen undersøger således, hvordan det er muligt at etablere lokalt ejerskab og styrke lærernes professionelle praksisser samt at udvikle nye læringskulturer rammesat og støttet af de nye platforme. Kapitlet skriver sig ind i det videnskabsfelt, som omhandler "ibrugtagning" af teknologi, særligt den gren som udvikler begreber om forandring og transformation af professionel arbejdspraksis, et område som særligt professor og direktør Yrje Engeström, Center for Research on Activity, Development and Learning (CRADLE), Helsinki Universitet, har stået i spidsen for.

\section{Formål}

Artiklen undersøger, hvorledes deltagerstyrede designprocesser som en kombination af fremtidsværksteder og designworkshops kan bidrage til at understøtte det pædagogiske personales ejerskab og lederskab i den faglige og pædagogiske ibrugtagning af læringsplatforme i skolen. Artiklen er udarbejdet med afsæt i Læringsplatformsprojektet. Artiklen baserer sig primært på et casestudie fra en af case-skolerne suppleret med tværgående data fra fokusgruppeinterview og en spørgeskemaundersøgelse med alle lærerne som deltog i projektet. 


\section{Teori og metode}

Læringsplatforme er et relativt nyt fænomen - særligt i folkeskolen. Til forskel fra enkeltstående teknologier er der tale om integrerede teknologier og services bundet sammen i en fælles platform. Disse kobler sig til allerede eksisterende praksisser på flere måder. Mikala Hansbøl (2010), som er docent og forsker i IKT og læring, taler derfor heller ikke i ental om læringsplatforme, men introducerer perspektivet om læringsplatformationer (Hansbøl, 2010). Derved får hun også rettet opmærksomheden henimod, at læringsplatforme bør ses og vurderes i relation til de forskellige typer af undervisnings- og læreprocesser, som de skal understøtte, og ikke kun som interessante i sig selv. Hansbøl beskriver det således:

99 It is argued that a variety of points of departure for engagement in the Studynet [institutionens læringsplatform, LDH] move the positionings of the Studynet in multiple directions. Thus, inside the moving specificities of ICT integration, the variety of directions and partial (dis-)engagements and (dis-)connections coexist with them.

(Hansbøl, 2010, s. 95)

I artiklen "An Infrastructural Perspective on Implementing New Educational Technology" engagerer forfatterne (Bygholm \& Nyvang, 2009) sig i at udvikle et infrastrukturperspektiv og en forståelse af læringsplatforme som infrastrukturer for læring. På trods af at mange traditionelt betragter en infrastruktur som noget teknisk, som eksempelvis kloaker, vandledninger, elektricitet, så betoner forfatterne, at infrastrukturer er såvel tekniske som sociale og kulturelle konstruktioner, og endvidere, at noget først bliver en infrastruktur, når den bliver taget $i$ brug og er i brug.

Læringsplatforme har især været anvendt i undervisningsog læringsforløb inden for de videregående uddannelser. Det er derfor ret unikt, at fokus flyttes mod folkeskolen, og at læringsplatforme potentielt kommer til at udgøre en fælles infrastruktur for læring i folkeskolerne. De læringsplatforme, som skolerne skal vælge imellem er blevet udviklet på baggrund af en kravsspecifikation fra Kommunernes Landsforening (KL, 2016). I den indgår, at læringsplatformene skal løfte læringsindsatserne i den 
danske skole og bidrage til at realisere folkeskolereformen (UVM, 2012). Læringsplatformene i folkeskolen er særlige ved, at de er designet til at facilitere en særlig politik og didaktik om "Fælles Mål" og målstyret undervisning. Denne kraftige binding til Fælles Mål og målstyret undervisning er blevet drøftet intensivt af forligskredsen bag folkeskolereformen. Forligskredsen ${ }^{1}$ blev i maj 2017 enige om at bryde med den stærke målstyring, som alle landets skoler har været underlagt, siden reformen blev til. Fælles Mål er således blevet lempet, hvormed de mere end 3.170 underliggende færdigheds- og vidensmål bliver vejledende og ikke obligatoriske som først aftalt (Christensen, 2017). Indførelsen af læringsplatforme på de danske folkeskoler er et interessant eksempel på et uddannelsespolitisk initiativ, hvor læringsplatformene er tiltænkt en aktiv og integreret rolle i realiseringen af folkeskolereformen og udviklingen af en målstyret undervisningsdidaktik.

Allerede i 6o'erne udviklede organisationsforskeren H. J. Leawitt (1965) en organisationsanalysemodel, som påviste, at når en organisation indfører en ny teknologi, sker der en påvirkning og forandring i de øvrige elementer (struktur, opgaver, aktører) i en organisation. Det er denne forandring, som denne artikel interesserer sig for. Hvordan kan der skabes ejerskab til disse forandringsprocesser blandt fagprofessionelle, forældre og elever? Og hvordan kan disse forandringsprocesser tilrettelægges som læreprocesser?

\section{Arbejdspladsrelateret, deltagercentreret design og samarbejde}

Et centralt omdrejningspunkt i Læringsplatformsprojektet har været at udvikle nye relationer og samarbejdsformer mellem forskere, udviklingskonsulenter og det pædagogiske personale. Her trækker projektet blandt andet på nogle af metoderne og teknikkerne fra den skandinaviske tradition for arbejdspladsrelateret, deltagercentreret design og samarbejde (Ehn, 1989; Kyng \& Greenbaum, 1991). Centralt for den skandinaviske tradition er fokus på demokratiserende og involverende metoder af fagprofessionelle, og at kompetenceudvikling og udvikling af nye

1 Forligskredsen består af Socialdemokratiet, Radikale Venstre, Socialistisk Folkeparti, Venstre, Dansk Folkeparti og Det Konservative Folkeparti. 
faglige praksisser sker med integration af teknologi. Selv om den skandinaviske tradition er udviklet årtier tilbage, finder vi, at der med dens fokus på de fagprofessionelle og kompetenceudvikling i forbindelse med implementering af teknologi og udvikling af teknologi er mange ligheder til den situation, som lærerne står i. Læringsplatformsprojektet ses derfor også som en anledning til at genbesøge nogle af de metoder, som er blevet brugt flittigt i den skandinaviske tradition. En af disse metoder er fremtidsværkstedet, som oprindeligt er udviklet af Robert Jungk and Norbert Müllert i slutningen af 5o'erne (Jungk \& Müllert, 1984). I Læringsplatformsprojektet er fremtidsværkstedet koblet med designværksteder, og de to metoder er blevet tilpasset til en travl skolekontekst. Denne artikels forfatter har særligt haft ansvaret for at udvikle og tilpasse fremtidsværkstedet (DirckinckHolmfeld \& Ræbild, 2017), medens Karsten Gynther har haft ansvaret for designværkstederne (Gynther, 2017)

\section{Data}

Læringsplatformsprojektet er et storskala-projekt med 15 case-skoler, som har dannet grundlag for udforskningen af ibrugtagningen af læringsplatforme. På alle skoler har der været afholdt et fremtidsværksted og en designworkshop, som forberedelse af en intervention i brugen af læringsplatformen, samt et videndelingsseminar, hvor erfaringerne fra interventionerne blev præsenteret, drøftet og begrebsliggjort. På nogle skoler deltog kommunens skolekonsulenter også i videndelingsseminaret. Udviklingsarbejdet på skolerne blev faciliteret af et team bestående af mindst en forsker og en udviklingskonsulent. Foruden at deltage i workshops og forestå interventionerne, har de deltagende lærere udfyldt en detaljeret logbog i forbindelse med interventionen, ligesom de har deltaget i fokusgruppe-interviews og et tværgående spørgeskema. Derudover har alle skoleledere for case-skolerne deltaget i et interview. Der har været 27 forskere og udviklingskonsulenter tilknyttet projektet, hvilket i sig selv har været en spændende og lærerig proces i forhold til at få skabt et fælles metodisk grundlag for dataindsamlingen.

Denne artikel baserer sig primært på data fra én case-skole, hvor artiklens forfatter sammen med en udviklingskonsulent og en videnskabelig medarbejder faciliterede udviklingsarbejdet. Artiklen bygger på data fra fremtidsværksted og designworkshops, videooptagelse af de to workshops, indholdslogs baseret på 
videooptagelser, billeder, transskriptioner af det pædagogiske personales designmaterialer, observationsnoter og logbøger. Linett Ræbild har som videnskabelig medarbejder forestået dataindsamlingen samt transkriptionerne. Endvidere har hun foretaget analyser af data ud fra en virksomhedsteoretisk analyseramme udviklet på baggrund af Engeströms "activity system analysis" (Engeström, 2001; Dirckinck-Holmfeld \& Ræbild, 2016)

\section{Fremtidsværksteder som afsæt for ibrug- tagning af digitale læringsplatforme i skolen}

Fremtidsværkstedsmetoden er af ældre dato, men det gør den ikke mindre velegnet i forhold til udviklingsarbejde i skoler. Udviklerne af metoden, Jungk og Müllert (1984), beskriver efterkrigstiden i slutningen af 50'erne som en tid med demokratisk underskud. Idéen var at gå bag om "eksperterne" og i stedet interessere sig for de idéer, drømme og erfaringer, som almindelige borgere og professionelle praktiserer i det levede liv. Robert Jungk udtrykker det således i forordet til Håndbog $i$ Fremtidsvoerksteder:

99

Først lidt efter lidt gik det op for mig, at jeg dermed (gennem fremtidsværksteder) havde gjort en "social opfindelse". Jeg havde taget begrebet om "demokrati" alvorligt og forsøgt at give "demos" (folket) mulighed for at tage del i den politiske proces på en mere intensiv og fantasifuld måde, end det normalt plejer at være tilfældet i det repræsentative demokrati, og dermed havde jeg påbegyndt noget nyt - noget der egentlig skulle have været praktiseret langt tidligere.

(Jungk \& Müllert, 1984, s. 7)

Fremtidsværkstedet bygger på et humanistisk dannelses- og demokratiperspektiv, som handler om at inddrage og gennem inddragelsen at give hver enkelt deltager en oplevelse af, at hans/ hendes tanker er værdifulde, og at disse bør inddrages i forhold til at berige en kollektiv skabelsesproces.

99 Et vellykket 'fremtidsværksted' kan man kende på, at det bereder deltagerne fornøjelse, at det styrker deres selvtillid, at det giver hver enkelt deltager en følelse af, at deres tanker er værdifulde, deres liv betydningsfuldt. Og der danner sig 
gennem denne kollektive skabelsesproces nye fællesskaber, der ikke blot er forenet gennem oplevelsen af den fælles skabende aktivitet, men tillige gennem den fælles opgave, der består i at give deres beskedne, men uundværlige bidrag til at forandre og forbedre en verden i krise.

(Jungk \& Müllert, 1984, s. 9)

Fremtidsværkstedet giver samtidig en uvurderlig indsigt i den professionelle og daglige praksis og bidrager således til, at de løsninger, som udvikles, kan tilpasses til og tage udgangspunkt i disse erfaringer og idéer og hermed bidrage til, at nye løsninger bygger på disse indsigter. Endvidere skaber inddragelsen "en vilje til forandring, til den daglige kamp mod rutinen "[...] Modet til selv at tænke og finde på styrkes i en sådan grad, at den trang til passivitet og tilpasning, som ligger i os alle, kan overvindes" (Jungk \& Müllert, 1984, s. 8-9).

Det er disse grundlæggende overvejelser om fremtidsværksteder, som har inspireret Læringsplatformsprojektet til at anvende denne metode. Gennem fremtidsværksteder ønsker Læringsplatformsprojektet således at inddrage det pædagogiske personale som de reelle eksperter i den pædagogiske og faglige skolepraksis i udviklingen af en læringsplatformsdidaktik og i tilegnelsen og den kontinuerlige videreudvikling af meningsfulde pædagogiske praksisser med læringsplatformen. Selv om denne artikel har fokus på det pædagogiske personale, betyder det ikke, at ledelserne ikke spiller en vigtig rolle i implementeringen. Rapporten "Anvendelse af digitale læringsplatforme og læremidler" (Svensson et al., 2017) dokumenterer, at der er et mønster i samspillet mellem ledelsen og det pædagogiske personale i forbindelse med implementering. På de skoler, som har en aktiv og engageret ledelse, som tager digital ledelse på sig og faciliteterer forandring, indgår læringsplatformen som et aktiv for skoleudvikling og skolens samlede pædagogik.

\section{Designworkshops}

I dette projekt har vi, som ovenfor beskrevet, koblet fremtidsværksteder med designværksteder. Inspirationen hertil kommer fra det eskalerende felt kaldet "design thinking", som blandt andet er groet frem på baggrund af metoderne og erfaringerne fra virksomheden IDEO i Silicon Valley (Brown \& Katz, 2009). Design 
thinking handler som udgangspunkt om at designe - at anvende tilgængelige tekniske ressourcer til at matche menneskelige behov, men design thinking går skridtet videre, idet design opfattes som en metode alle mennesker kan gøre brug af - også mennesker, som aldrig har forstået sig selv som designere, lige som det heller ikke kun drejer sig om at skabe tekniske løsninger. Design thinking arbejder med tre overlappende felter: Inspiration, problem eller mulighed, som motiverer for at skabe løsninger; ideudvikling, som er processen med at generere, udvikle og teste ideer, og endelig implementering, som er fasen, der leder et projekt fra projektrummet og til markedet (Brown \& Katz, 2009, s. 16). Og ligesom fremtidsværkstedet arbejdes der med at kombinere de rationelt analytiske videns- og handleformer med emotionelle, non-lineære og intuitive. Design thinking handler overordnet set om at skabe forandring gennem at designe løsninger.

I forhold til den traditionelle måde at afholde fremtidsværksteder har vi i Læringsplatformsprojektet erstattet den sidste fase af fremtidsværkstedet med designeksperimenter. Et fremtidsværksted består typisk af en kritikfase, en fantasifase og en virkeliggørelsesfase (i den nævnte rækkefølge) (Jungk og Müllert, 1984, s. 55-87). I læringsplatformsprojektet har vi brugt fremtidsværkstedet som udgangspunkt for kritik- og fantasifasen. Virkeliggørelsesfasen, som også rummer en opfølgningsfase, har været udformet som designeksperimenter efterfulgt af en periode for afprøvning af design. Den kritiske læser kan med god ret stille spørgsmålet, om vi ikke kunne have nøjedes med den ene af metoderne - enten fremtidsværkstedet eller design workshops. Min begrundelse for at kombinere de to metoder er dog, at selv om deres faser på overfladen minder om hinanden, så har de forskellige erkendelsesinteresser. Ved at kombinere dem får vi, populært sagt, taget det bedste fra to verdener og bragt dem sammen. Fremtidsværkstedets styrke er at skabe kritisk indsigt og bevidsthed som baggrund for handling, ligesom fremtidsværkstedet har et klart demokratiseringsperspektiv, som handler om at engagere og deltage. Heroverfor er designværksteder en mere håndgribelig måde at arbejde med at designe løsninger og dermed skabe forandring (og erkendelse) gennem design. Begge metoder er rettet mod, at løsningerne skal kunne bruges, ligesom begge metoder fokuserer på, at det er handling, som skaber forandring og indsigt.

Læringsplatformsprojektets idé om at inddrage fremtidsværksteder og designværksteder som metode skal derfor også 
ses som en måde at inddrage det pædagogiske personale som partnere og som de reelle eksperter i en fælles proces om at forstå, udforske, tilegne, ibrugtage og kontinuerligt videreudvikle læringsplatformene. Fremtidsværkstedet har skabt en ramme for, at lærerne fælles har kunnet udvikle forståelse for og oplevelse af læringsplatformen og deres visioner i forhold til udvikling af lærerarbejdet og elevernes læreprocesser, medens design-eksperimenterne har givet det pædagogiske personale mulighed for systematisk at afprøve nogle indsatser, som de fandt vigtige for deres praksis (uddybes nedenfor). Koblingen af de to metoder er vigtig for at skabe engagement og ejerskab til læringsplatformen, tilegne sig konkrete erfaringer i brug samt understøtte en udforskende kultur blandt det pædagogiske personale.

\section{Erfaringer fra case-skolens fremtids- værksted og designeksperimenter}

Syv lærere deltog i fremtidsværkstedet og de efterfølgende designeksperimenter. Gruppen var sammensat af lærere fra de forskellige grundtrin, indskolingen, mellemtrinet og udskolingen, og af lærere fra matematik, dansk og de musiske fag. Fremtidsværkstedet startede med en kritikfase, hvor deltagerne brainstormede deres kritik relateret til brugen af læringsplatformen MinUddannelse. Deltagerne blev bedt om at formulere 3 kritikpunkter på farvet papir, der i stikord forklarede de vigtigste problemer relateret til MinUddannelse set fra deres perspektiv. Figur 1 viser et billede af nogle af kritikpunkterne. Øvrige kritikpunkter kan findes i bilag 8 (Dirckinck-Holmfeld, Nielsen \& Ræbild, 2016). 
Figur 1. Kritikudvælgelse, billede fra case-skole.
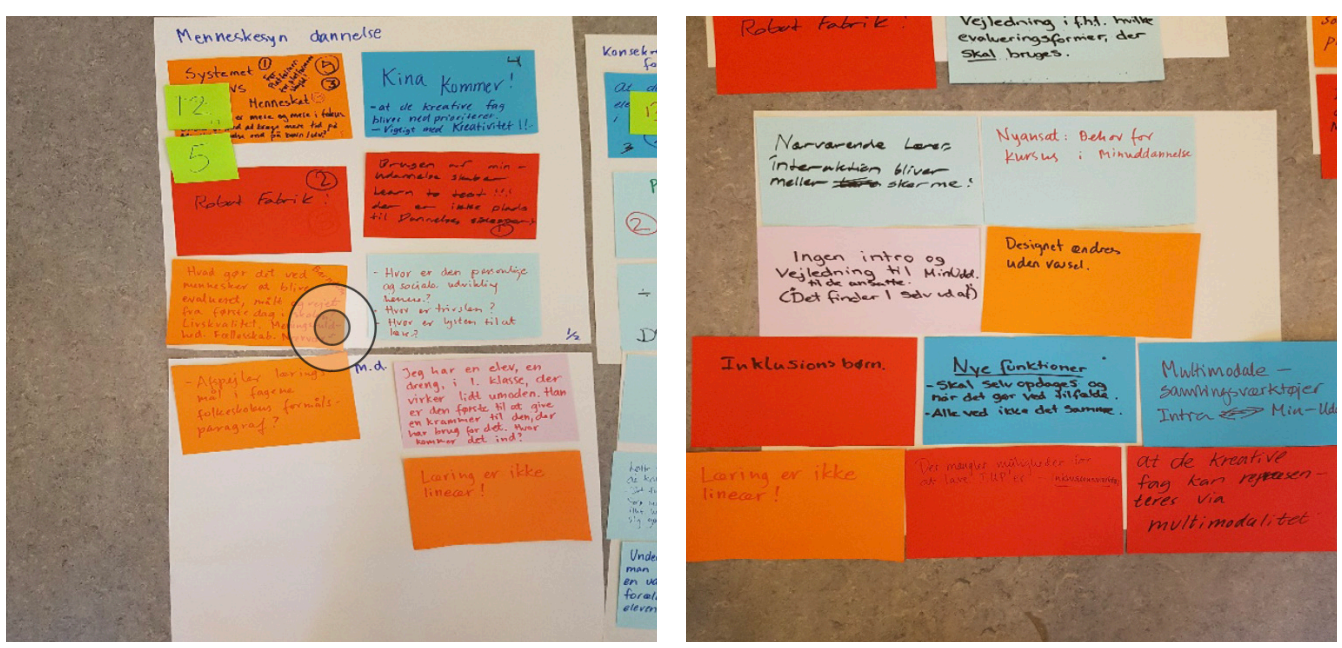

Efter hver deltager havde præsenteret sine 3 kritikpunkter, havde gruppen stadig flere relevante kritikpunkter, og processen fortsatte derfor, indtil emnet var udtømt. Der blev produceret 58 kritikpunkter i kritikfasen (Dirckinck-Holmfeld, Nielsen \& Ræbild, 2016). Alle deltagere fik derefter 10 point, som de kunne fordele på kritikpunkterne, for på den måde at foretage en kritikudvælgelse og prioritering. Nedenfor vises de kritikpunkter, der fik point i de forskellige temaer, og som udgjorde hovedfokus for den efterfølgende fantasifase. 


\begin{tabular}{|c|c|}
\hline Teknik og design & I alt 2 point \\
\hline Multimodale - samlingsværktøjer. Intra <-> MinUddannelse & 2 \\
\hline Didaktik & I alt 6 point \\
\hline $\begin{array}{l}\text { MinUddannelse er svær at gøre til en integreret del af undervisningen. } \\
\text { (Mere til forældre end børn) }\end{array}$ & 2 \\
\hline Det er ikke lavet/designet til indskolingen & 2 \\
\hline Den er ikke god til kompetencemål & 2 \\
\hline Lærerens brug af MinUddannelse & I alt 12 point \\
\hline Der er for lidt vejledning ift., hvilke evalueringsformer, der skal bruges & 8 \\
\hline $\begin{array}{l}\text { Ingen intro og vejledning til MinUddannelse til de ansatte. } \\
\text { (Det finder I selv ud af) }\end{array}$ & 1 \\
\hline Man ejer ikke sine egne forløb & 2 \\
\hline Nyansat: Behov for kursus i MinUddannelse & 1 \\
\hline Menneskesyn - dannelse & I alt 32 point \\
\hline $\begin{array}{l}\text { Systemet vs. mennesket. Platformen for platformens skyld! } \\
\text { Platformen er mere og mere i fokus. Ender vi med at bruge mere tid } \\
\text { på MinUddannelse end på børn IUV? }\end{array}$ & 17 \\
\hline $\begin{array}{l}\text { Kina kommer! At de kreative fag bliver nedprioriteret. } \\
\text { Vigtigt med kreativitet!! }\end{array}$ & 4 \\
\hline Robotfabrik & 5 \\
\hline $\begin{array}{l}\text { Brugen af MinUddannelse skaber "teaching to test"! } \\
\text { Der er ikke plads til dannelse }\end{array}$ & 1 \\
\hline $\begin{array}{l}\text { Barndom: Hvad gør det ved mennesker at blive evalueret, målt og } \\
\text { vejet fra første dag i skolen? Livskvalitet. Meningsfuldhed. Fællesskab. } \\
\text { Nærvær }\end{array}$ & 5 \\
\hline Konsekvenser af brugen af MinUddannelse for børn og forældre & I alt 18 point \\
\hline De allersvageste elever bliver tabere i et stringent system & 13 \\
\hline De dygtige elever bliver stressede af de mange mål, der skal opnås & 1 \\
\hline Praleværksted & 2 \\
\hline Minus procesorienteret & 2 \\
\hline
\end{tabular}

Det er interessant, at temaet "Teknik og design" er et af de temaer, deltagerne skrev flest kritikpunkter til, men i pointgivningen gav de ikke temaet høj prioritet. Temaet "Menneskesyn - dannelse" havde ikke så mange forskellige formuleringer, men de kritikpunkter, der blev formuleret fik mange point af deltagerne. Dette tolker vi således, at selv om udgangspunktet for kritikken var de mere umiddelbare tekniske udfordringer, som knytter sig til læringsplatformen, så gav kritikfasen anledning til at italesæt- 
te mere grundlæggende idéer og problemstillinger i forhold til læringsplatformen.

\section{Fantasifasen}

De syv deltagere var delt op i 2 grupper (selvvalgte) i fantasifasen. Formålet var, at deltagerne skulle drømme og fantasere om, hvordan den ideelle brug af MinUddannelse kunne se ud fra deres perspektiv. Fantasiudkastet skulle ske på baggrund af mindst et af de temaer, som blev identificeret i kritikfasen. Deltagernes visioner blev i stikordsform sammenfattet i nedenstående liste:

\section{Deltagernes visioner}

Tabel 3. Stikord fra visionsfase, caseskole.

\section{Opgør med målkultur/ændring af menneskesyn - Gruppe 1}

- De vil gerne tilbage til dengang, læring var en proces og ikke kun et mål.

- I ræset mod læringsmålene, skal de både have hjernen og hjertet med.

- Der skal være mere tid til at tage sig af børnenes individuelle forskelle.

- Forældre skal ikke kun kunne se resultaterne, men processen hen imod målet.

- Trivsel skal være et mål i sig selv.

- MinUddannelse skal omfavne, at det at fejle er en del af at lære.

- Trivsel, dannelse og det faglige skal afspejles i højere grad i MinUddannelse, da forældrene kan få et forkert indtryk af, hvordan det går med deres barn, når MinUddannelse kun fokuserer må mål/resultater.

- Lærerne skal få en form for notifikation, når der kommer nye funktioner eller lignende.

- Læreren skal lede vejen ift. brugen af MinUddannelse og have fuldstændigt styr på hvordan og hvorfor.

- MinUddannelse skal kunne benyttes på alle klassetrin (forskellige funktioner, der er relevante ift. klassetrin).

- MinUddannelse skal være lettere at inkludere i de humanistiske fag, hvor det er sværere at bruge sort/hvide mål.

- Der skal være mere fokus på dannelse i stedet for kun faglighed (Formålsparagraffen skal agere ledestjerne for MinUddannelse).

- MinUddannelse skal give mening for lærerne at bruge i forhold til deres praksisvirkelighed. 


\section{Andre evalueringsformer og en anden læringsforståelse - Gruppe 2}

- Der burde være en off/on knap i MinUddannelse for selvevaluering, da dette ikke burde være aktuelt i de små klasser.

- Pokaler (belønning for mål) skal erstattes med læring via leg.

- Der skal være mere plads til leg i MinUddannelse.

- Der skal kunne evalueres inde på platformen på andre ting, end dem MinUddannelse lægger op til ( $f x$ Lego Build to Express/kreative fag).

- Der skal være tid/mulighed for at tage udgangspunkt i det enkelte barn.

- Der skal skæres ned på mål og målkulturen, da den forhindrer problemorienteret arbejde.

Den ene gruppe fokuserede især på, at platformen skal gennemsyres af et etisk-humanistisk grundsyn, hvor barnet sættes i centrum med fokus på, at barnet er nogen og ikke noget. For det pædagogiske personale handler det om på alsidig vis at udvikle og danne barnet som en person (blive nogen) og ikke en ting eller en robot (ikke-noget), som nogle udtrykte det. Læringsplatformen i sin nuværende udgave forbindes således med et teknisk-rationelt menneskesyn. Som formuleret i et af kritikudsagnene: "Barndom: Hvad gør det ved mennesker at blive evalueret, målt og vejet fra første dag i skolen? Livskvalitet. Meningsfuldhed. Fællesskab. Nærvær?” (Kritikudsagn, Tabel 1). Særligt lærerne inden for det humanistiske og musiske område udtrykte et ønske om, at læringsplatformen kunne understøtte og stimulere holistiske, multimodale og skabende arbejdsformer. Lærerne efterspurgte endvidere, at læringsplatformen ville understøtte konstruerende læreprocesser eksempelvis problem- og projektorienterede undervisningsforløb og skolens særlige koncept for ude-skole, samt at læringsplatformen ville opfordre til at inddrage leg og fx brugen af Lego og andre fysiske værktøjer til støtte for børnenes udvikling i større grad. Det var karakteristisk, at i lærernes visioner for en læringsplatform, så indgår den som et integreret, naturligt ${ }^{2}$ og brugbart værktøj til at understøtte virkeliggørelsen af et humanistisk dannelsesideal, ligesom den ses som

2 Naturligt i betydningen, at læringsplatformen er "ready-to-hand", et begreb lånt fra Heideggers eksistentielle fænomenologi, hvor værktøjet indgår som en måde "at være-i-verden", således at lærernes opmærksomhed ikke er på læringsplatformen, men kan være på de pædagogiske og faglige processer (Ehn, 1989). 
støtte for og forankring af de konstruktivistiske og produktive lærings- og arbejdsformer, som de ønsker at styrke (se Figur 2 og 3).

Figur 2. Gr. 1: Barnet er "nogen", ikke "noget".

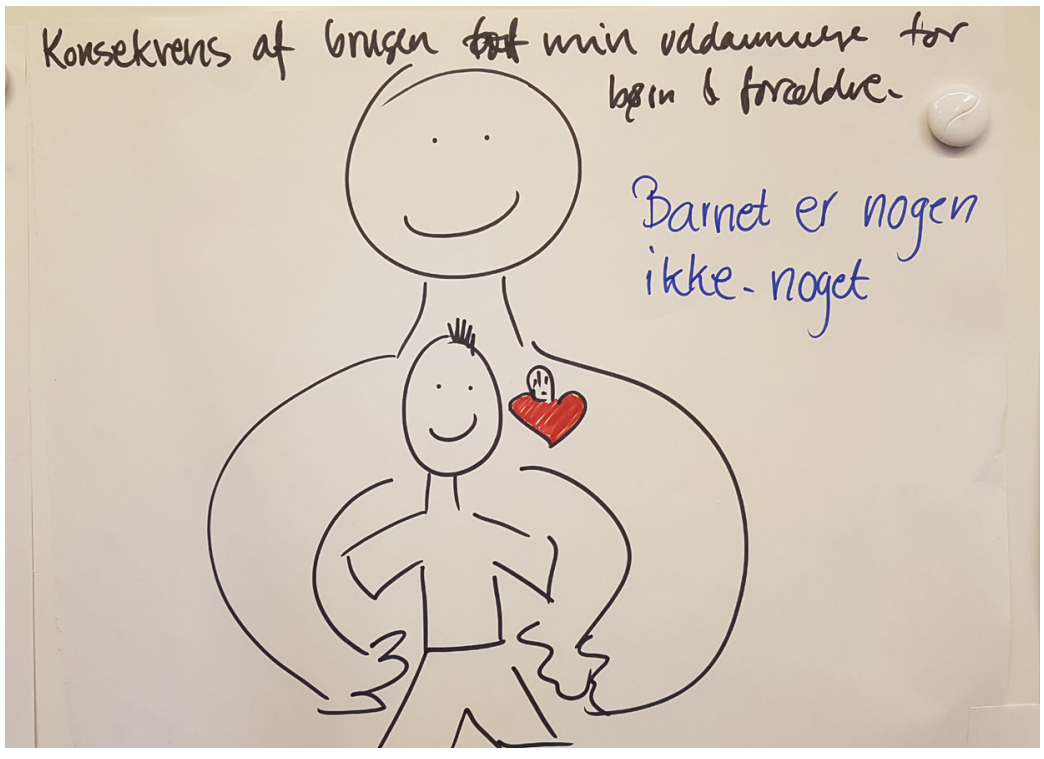

Figur 3. Gr. 2: Børn gør, hvad de kan.

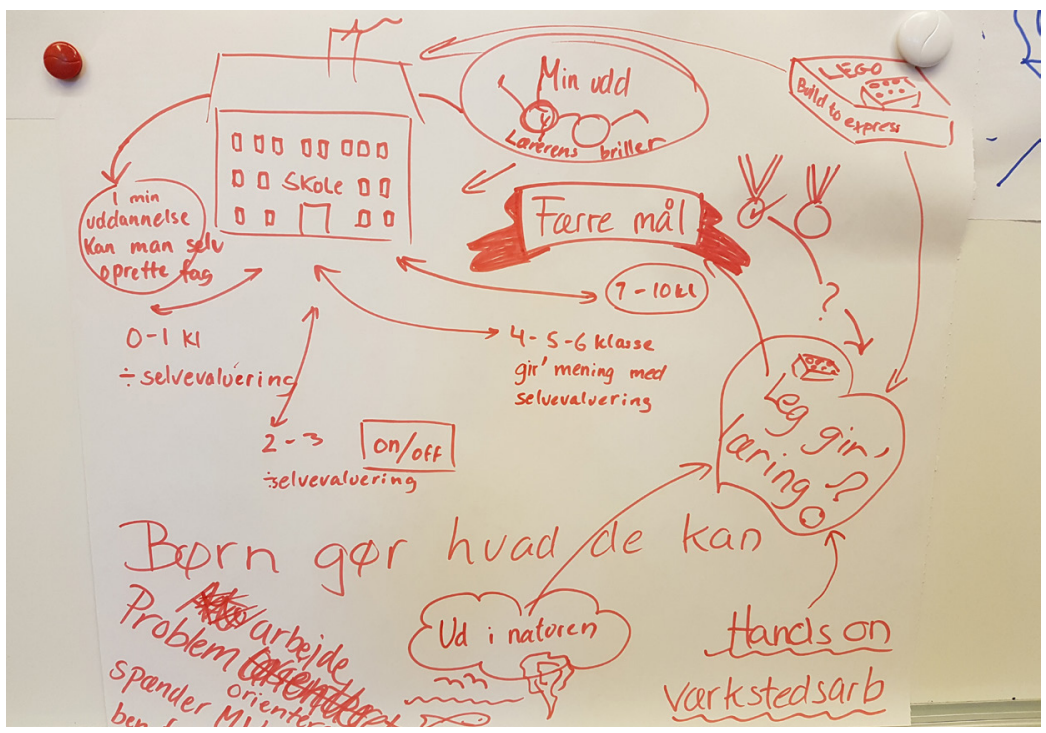


Fremtidsværkstedet blev analyseret ved brug af Engeströms (2001) aktivitetsanalysemodel (ASA). Modellen hjalp til at få identificeret nogle af de modsætninger, som lærerne oplever i forhold til læringsplatformen (se Figur 3).

Hovedproblemstillingen, som identificeredes i kritikfasen, og som kom til at sætte rammen for fantasifasen og den efterfølgende designworkshop, omhandlede det menneskesyn, som lærerne mente, at MinUddannelse er bygget på. Ifølge lærerne lægger MinUddannelse op til en undervisningspraksis, som ikke ser børnene "som nogen, men som noget, der hele tiden skal måles og vejes". Dette er særligt i forhold til læringsmål. Modellen neden for illustrerer dette modsætningsforhold (Figur 4) og er baseret på en analyse af videodata fra fremtidsværkstedet, blev der identificeret 10 temaer med modsætningsforhold. De resterende analyser kan findes i Bilag 3 (Dirckinck-Holmfeld, Nielsen \& Ræbild, 2016) og er opsummeret nedenfor.

Analysemodellen skal læses som følger: Undervisningspraksis er formidlet af værktøjet: MinUddannelse. For subjektet (lærerne) er målet, at eleverne skal tilegne sig en eksperimenterende læringskultur, og at det er ok at eksperimentere, forsøge og fejle, og at fejl er en naturlig proces, når man lærer nye ting. Men lærerne oplever dette som en spænding i aktivitetssystemet mellem reglerne i MinUddannelse og objektet (formålet). 
Figur 4. ASA-analyse: Menneskesyn/ vurdering af børn. Pilene angiver spændinger. (Farverne har ingen særlig betydning).

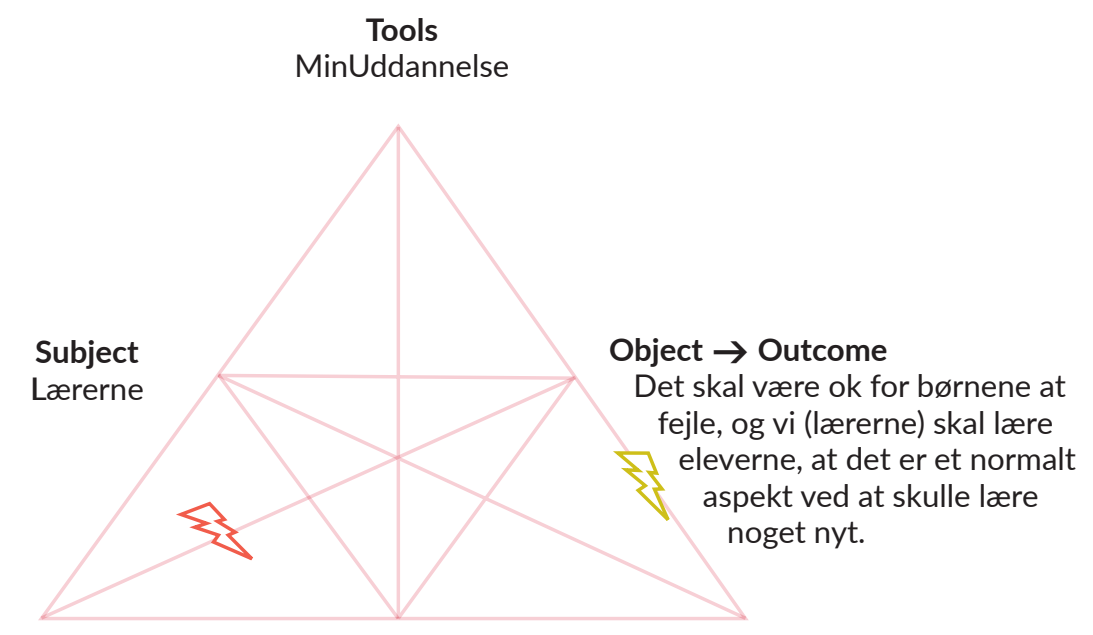

\section{Rules}

Det er pt. ikke ok for børnene at fejle. Læring ses ikke som en proces $\mathrm{i}$ MinUddannelse, hvor det at fejle er en naturlig del af den processen. Det er bygget op om alt/intet og sort/hvidt.

\section{Community}

Lærer-kollegaer, skoleledelsen, Aalborg kommune, børnenes forældre, Designere/ ejere af MinUddannelse.

\section{Division of Labour} Børnene skal leve op til nogle bestemte krav inden for en bestemt tidsramme. Lærerne skal evaluere på baggrund af, hvad de ser lige nu.

MinUddannelse bygger på kompetence og beherskelse som absolutte kategorier, "alt eller ingenting", "sort eller hvidt", som en af lærerne formulerer det. I stedet ser lærerne læring som en proces af beherskelse over tid. Dette skaber også en anden spænding for lærerne, fordi de netop skal afgøre, om en elev mestrer en opgave inden for en meget specifik tidsramme og ikke $i$ et længere perspektiv eller gennem en proces. De identificerede spændinger mellem MinUddannelse og lærerne er udtryk for et modsætningsforhold i evalueringskultur, og at systemet pålægger en "digital evalueringsstandard" som en af lærerne udtrykker det baseret på en absolut skala udtrykt i "kan/kan ikke". Samme lærere efterspørger, at læringsplatformen kan understøtte mere formative og procesorienterede evalueringer, og at læringsplatformen kan stimulere udviklingen af en eksperimenterende læringskultur med plads til at "forsøge" og "fejle".

Community forstås i modellen som alle aktører: Lærerne, 
skolens ledelse og ledere, forældrene, eleverne, skoleledelsen i kommunen og udviklere af MinUddannelse.

På baggrund af flere ASA-analyser (Dirckinck-Holmfeld, Nielsen \& Ræbild, 2016) blev følgende spændinger identificeret mellem lærernes mål og MinUddannelse som værktøj (Tabel 5):

Tabel 5. Stikord, spændinger - ASA-analyse

i forbindelse med evaluering.

\section{Spændinger i forbindelse med evaluering og fastsættelse af læringsmål}

- Formålet (objekt) er at inddrage eleverne i evalueringen <-> elevernes mangel på selvbevidsthed + utilstrækkelige værktøjer.

- Formålet (objekt) er at anvende en mere differentieret evalueringsform <-> platform giver standardiserede evalueringer.

- Formålet (objekt) er en nuanceret, men forudsigelig måde at evaluere eleverne på <-> for mange forskellige mål for eleverne (en elev havde 34 mål).

- Formålet (objekt) er at give en "fair" evaluering af eleven <-> ikke synlige kriterier for evaluering, kan / kan ikke evaluering.

- Formålet (objekt) er, at platformen skal gavne elevernes læring <-> forældrene bruger platformen mere end børnene. Det er til "show".

- Formålet (objekt) er, at det skal være ok og naturligt at fejle for at lære <-> læring ses ikke som en proces i platformen. Lærerne skal evaluere fragmenterede øjeblikke.

Tabel 6. Stikord: Spændinger ASA-analyse i forbindelse med pædagogisk brug.

\section{Spændinger relateret til den pædagogiske brug af MinUddannelse}

- Formål (objekt) er en "børnevenlig" platform

<-> For meget tekst hindrer de yngre elever i at arbejde med platformen.

- Formål (objekt) er multimodal undervisning

<-> for kompliceret til at bruge platformen i et multimodalt arbejde (ophavsretlige problemer, dobbeltarbejde).

- Formål (objekt) er mere problemorienteret / kreative undervisningsmetoder <-> Andre lærere har altid adgang til andres lektionsplaner.

Du skal måske svare på din specifikke lektionsplan.

- Formål (objekt) er for lærere at vide præcis, hvad de laver med platformen og hvorfor <-> Lærere undgår systemet, fordi det ikke er tilpasset deres værdisystem. 


\section{Designeksperimenter}

Fremtidsværkstedet blev fulgt op med et designværksted, hvor lærerne skulle udvælge samt udvikle et design for en konkret indsats, som de ønskede at sætte i værk. Det pædagogiske personale formede to design-grupper. Som optakt til designworkshoppen gav forskergruppen en opsummering af fremtidsværkstedet og præsenterede ASA-analyserne på baggrund af nogle plancher af virksomhedsteoriens "aktivitetsmodeller" med indtegninger af de identificerede spændinger og modsætninger (se eksempel i Figur 4). ASA-analyserne kom således til at tjene som en slags spejl for deltagerne, hvor den grafiske repræsentation af aktivitetsmodellen tydeliggjorde de modsætninger og spændinger, som det pædagogiske personale havde drøftet i fremtidsværkstedet. Jeg fortolker deres brug af modellerne således, at de var meget tilfredse med at "få noget tilbage" fra forskergruppen, og at det var meget befordrende for den videre proces i forhold til at fastholde fokus og formulere og planlægge interventionen.

Med afsæt i ASA-analyserne i kombination med det pædagogiske personales interesser og visioner for udvikling og afprøvning, valgte de to grupper to design-eksperimenter, som de $\emptyset$ nskede at fokusere på, henholdsvis 1. En afprøvning af portfolio og formativ evaluering og 2. Anvendelse af MinUddannelse i skole-hjem-samarbejdet. Gruppe 1's valg lå i naturlig forlængelse af lærernes interesse for at udvikle mere procesorienterede evalueringsmetoder (se Tabel 3). Gruppe 2's valg var også begrundet i en overordnet interesse for evaluering (Tabel 3), men med en særlig optagethed af, hvorledes læringsplatformen kan anvendes i samarbejdet med forældrene i forhold til at gavne elevernes læring. Der var på forhånd udarbejdet et omfattende materiale til at guide det pædagogiske personale i design-processen. Alligevel var en af vores (forskernes) iagttagelser, at det tilsyneladende var vanskeligere for deltagerne at arbejde i design-fasen. I flere tilfælde fortsatte deltagerne således de kritiske drøftelser fra fremtidsværkstedet i stedet for at påbegynde den konkrete idéudvikling og planlægning af implementeringen. Begge grupper nåede dog frem til at planlægge deres intervention. Efter designworkshoppen fik det pædagogiske personale godt to måneder til at afprøve designeksperimenterne med eleverne og forældrene. Parallelt hermed udfyldte lærerne en logbog om deres oplevelser og erfaringer. Eksperimenterne afsluttedes med et fælles videndelingsseminar, hvor hver enkelt gruppe detaljeret gennemgik deres eksperimenter, deres erfaringer og deres læring først i en drøf- 
telse med forskergruppen og lederen fra skolen og efterfølgende i en fælles drøftelse med kommunens uddannelsesansvarlige og den pædagogiske konsulent.

\section{Diskussion af resultater og erfaringer fra casestudiet}

Designeksperimenter og designtilgang er en ny tilgang for lærerne, som gav dem en konkret og situeret oplevelse af de muligheder og begrænsninger, som knytter sig til MinUddannelse. På videndelingsseminaret fremgik det, at lærerne stadig opfattede MinUddannelse som overvejende reduktionistisk i forhold til børnene, men de havde samtidig også fået nogle konkrete oplevelser af, hvordan udvalgte værktøjer i MinUddannelse kan anvendes til at realisere deres pædagogiske intentioner. Med reference til Engeströms begreb om ekspansiv læring (Engeström, 2001) kan det hævdes, at læringsplatformen indenfor de to områder, som grupperne valgte at arbejde med, har fungeret som et springbræt for at realisere elementer af målstyret undervisning på nye måder. For en gennemgang af læringen $\mathrm{i}$ tilknytning til designinterventionerne henvises til "Delrapport 2: Fremtidsværksted, brugerindflydelse og ejerskab - om at understøtte det pædagogiske personales ejerskab og fagligt pædagogiske lederskab i brug af læringsplatforme" (Dirckinck-Holmfeld \& Ræbild, 2017). Her skal blot gives et eksempel på, at lærerne med de konkrete interventioner får en mere nuanceret forståelse af, hvordan værktøjet kan bruges samtidig med, at de også får identificeret konkrete udfordringer og mangler ved værktøjerne.

På designværkstedet fik gruppe 1 indsigt $\mathrm{i}$, at der fandtes en portfolio-funktion i MinUddannelse. Gruppen besluttede derfor, at de ville arbejde med denne funktion i MinUddannelse for at eksperimentere med formativ evaluering. Konkret ville de arbejde med, om eleverne kunne opnå kendskab med portfolioteknikken ved at uploade dokumenter og etablere en arbejdsportfolio. Endvidere ville de undersøge, hvor lærernes og elevernes refleksioner i forhold til portfolioen skulle ligge.

Brugen af portfoliofunktionen blev afprøvet i tilknytning til et multimodalt danskforløb i MinUddannelse i 5 . klasse om "nonsensdigte". Eleverne skulle i par arbejde med at skabe og udvikle "nonsensdigte". Til støtte for deres arbejde benyttede eleverne en række værktøjer, som de plejede at benytte på deres iPad (kamera, diktafon og Book Creater). Et af de problemer, som lærerne 
stødte på, var, at portfolio-funktionen var designet til at understøtte individuel upload af opgaver, medens lærerne ønskede, at eleverne kunne uploade opgaverne parvis og således, at begge elever fik uploadet opgaven i deres portfolio og blev registreret som havende uploadet opgaven. Dette kunne umiddelbart ikke lade sig gøre, og underviseren måtte derfor lave nogle yderligere manuelle tiltag for at få registreret alle eleverne og uploadet opgaven til alles portfolio. Dertil kom, at der var udfordringer med teknisk kompabilitet mellem nogle af værktøjerne og MinUddannelse.

På baggrund af interventionen rejste forskergruppen spørgsmålet om, hvilke typer af læring der fandt sted i forbindelse med interventionen medieret af de forskellige værktøjer. Lærerne plejer at køre et forløb med børnene, hvor de skal bruge deres iPads til at producere "nonsensdigte". Ifølge lærerne kører det som rutine. Undervisningen er generelt forudsigelig, og én lærer er almindeligvis tilstrækkeligt. Men i forbindelse med upload i portfolioen opstår der problemer. Læreren må ty til nogle manuelle tiltag for at få alle børnene registreret og opgaven uploadet. Dette er meget forstyrrende for læreren, og læreren bringes ud af sit "flow" med eleverne. Læreren oplever således et brud på det operationelle niveau. Fra at have fokus på de pædagogiske og evalueringsfaglige problemstillinger i forhold til de enkelte børn, bliver læreren nødt til at skifte fokus og fokusere på de tekniske udfordringer. Disse løses konkret ved at inddrage it-vejlederen.

På trods af disse tekniske udfordringer, får læreren og eleverne dog en oplevelse af portfolioens muligheder i forhold til det enkelte barn og det enkelte fag. Det opleves, at det er muligt (med modifikationer) at samle elevens multimodale arbejdsprodukter, og det opleves, at disse vil kunne danne udgangspunkt for en mere procesorienteret evaluering. Så på trods af en del besværligheder på et praktisk niveau, så gav portfolioværktøjet en smag på de muligheder, som allerede findes i MinUddannelse for at understøtte en producerende og multimodal pædagogik.

For at der kan tales om ekspanderende læreprocesser, skal der ifølge Engeström findes en alternativ løsning, som overskrider situationens konstituerende betingelser (Engeström, 2001). At arbejde med portfolio-funktionen for at fremme producerende og multimodale pædagogiske former og tilsvarende evalueringsformer er eksempler på læreprocesser, som overskrider den værdiorientering, som qua målstyringen dominerer MinUddannelse. Lærerne opdagede dog samtidig i forbindelse 
med udforskningen af portfolio-funktionen, at den var designet med sigte på den enkelte elev - ikke med et kollaborativt sigte, og endvidere, at portfolio-funktionen ikke var designet med henblik på at kunne gå på tværs af fagene.

I forhold til en "ibrugtagning" af læringsplatformen er det afgørende, at lærerne gennem de konkrete interventioner fik en oplevelse af, at værktøjet kunne tilføre nogle nye muligheder og strukturer til den formative evaluering og samarbejdet med forældrene. Som forskere kunne vi således iagttage, at lærerne fra at udtrykke stor skepsis i fremtidsværkstedet begyndte at kunne se muligheder i læringsplatformen inden for delaspekter, som kunne kvalificere deres arbejde med eleverne. Denne forståelse af læringsplatformen understøtter også Hansbøls begreb om "læringsplatformationer", hvor læringsplatformen kan udnyttes på forskellig vis (Hansbøl, 2010). Men måske er det endnu vigtigere, at lærerne i den systematisk tilrettelagte intervention påtager sig og tildeles lederskab i at kombinere og udforske værktøjet, principper og praksis på nye måder.

En af de kritiske teknologiforskningstraditioner, som kan forklare dette, er SKOT-traditionen (Social Construction of Technology). Som Pinch og Biiker (1984) skriver, så skaber teknologien som en teknisk og socialt konstrueret infrastruktur "rammer" for brugernes opfattelser, men disse er ikke determinerende og ændres netop i brug, jf. også begrebet om "fortolkningsmæssig fleksibilitet" (Pinch \& Bijker, 1984). En "teknologisk ramme" er en forståelse og opfattelse af løsninger og problemer, som knytter sig til en bestemt teknologi. En teknologisk ramme er bundet til forståelserne og designet fra én eller flere aktører og aktørgrupper i samfundet: "Når en teknologi er ny eller relativt uafprøvet i en bestemt sammenhæng, vil der være en 'fortolkningsmæssig fleksibilitet' i forhold til teknologien, som vil give sig til udslag i flere forskellige, konkurrerende teknologiske rammer" (Hoff, 2003, s. 143). De forskellige aktørgrupper konkurrerer om definitionsretten.

Denne beskrivelse af den sociale konstruktion af teknologi er også rammende for læringsplatformene. Her er tale om teknologier, som stadig er under udvikling, og som rummer en fortolkningsmæssig fleksibilitet. At få lærerne til at tage aktivt del i konstruktionen af disse "rammer" er afgørende for ibrugtagningen. Set i det lys kan fremtidsværkstederne og designtilgangen bidrage til, at det pædagogiske personale får et rum for at forhandle betydningen af læringsplatforme - og for at sætte den pæ- 
dagogiske brug i centrum. Den fortolkningsmæssige fleksibilitet i forhold til læringsplatforme er ikke "lukket" endnu. Tværtimod, kan man se disse første versioner af læringsplatformene, som udkast til nogle teknologiske rammer, som i første omgang responderer på kravspecifikationen udarbejdet af Kommunernes Landsforening (KL) som aktørgruppe og på baggrund af en skolereform. Som det også kom frem i fremtidsværkstedet, og særligt i designinterventionerne, er lærerne og det pædagogiske personale engagerede i at udforske mulighederne i læringsplatformene. For lærerne og det pædagogiske personale er det pædagogik og fagudvikling, som er i centrum for læringsplatformen som teknologisk ramme.

\section{Konklusion og resultater i forhold til fremtidsværksteder og designworkshops}

Kombinationen af fremtidsværksted og designværksteder har vist sig at spille godt sammen i en skolekontekst. Det pædagogiske personale har værdsat at blive inddraget som partnere $\mathrm{i}$ forhold til at drøfte politiske, værdimæssige, faglige og praktiske aspekter af læringsplatformen. Ligesom selvsamme deltagere har bidraget til aktiviteterne i forbindelse med designeksperimenterne.

De to metoder har spillet forskellige roller. Fremtidsværkstedet har primært fungeret som en effektiv metode til at få identificeret en konkret og empirisk-praktisk oplevelse af fænomenet (målstyret undervisning med MinUddannelse), som også knytter an til de dybere værdi- og dannelsesperspektiver, som er indlejret i læringsplatformen. Designeksperimenterne og interventionerne har forfinet og nuanceret denne oplevelse af fænomenet og, helt konkret, identificeret og belyst udfordringer og muligheder i forbindelse med virkeliggørelse af indsatserne.

\section{Fremtidsværkstedet som metode - erfaringer på tværs af alle deltagende skoler}

Fra den brede spørgeskemaundersøgelse med alle deltagerne, som er mere udførligt refereret i Dirckinck-Holmfeld \& Ræbild (2017) fremgår det, at det pædagogiske personale fra de deltagende skoler haft gode erfaringer med fremtidsværkstedet, og 
at fremtidsværkstedet har givet dem mulighed for at tage ejerskab i implementeringen (Dirckinck-Holmfeld \& Ræbild, 2017). Fremtidsværkstedet har endvidere bidraget til mere dialog og flere diskussioner med kollegaer og med ledelsen. Der er dog også enkelte, der fremhæver, at det var svært at være i kritikfasen, fordi de meget hellere ville bruge tiden til at finde frem til en konkret løsning i stedet for at spilde tid på at snakke. Og andre påpeger, at de netop ikke kan finde frem til konkrete løsninger, når det ikke var en del af den bundne opgave i projektet at ændre på platformen. Nogle følte sig også fastlåste i design-værkstedet, fordi de oplevede, at de alligevel ikke kunne bruge de visioner, de havde udtænkt i fremtidsværkstedet, fordi de var for radikale. Trods disse følelser af, at de alligevel ikke helt havde den indflydelse, som de havde håbet på, fremhævede de fleste, at fremtidsværkstedet alligevel havde åbnet for mange relevante refleksioner omkring deres arbejde både med og uden platformen. Blandt andet blev det fremhævet, at det havde været positivt, at fremtidsværkstedet flyttede fokus fra det tekniske til det didaktiske og pædagogiske. For en del skoler åbnede fremtidsværkstedet i sig selv op for nye perspektiver og problemstillinger, fordi lærerne normalt ikke får så lang tid til at diskutere didaktisk udvikling. Dertil kom, at lærerne værdsatte metoden, fordi den er praktisk og resultatorienteret.

\section{Afsluttende refleksioner}

Metoden med at kombinere fremtidsværksted, ASA-analysen (kun på én case-skole), designworkshops og små lokale indsatser har været afprøvet på 15 eksperimentskoler. Et tydeligt fund, der går på tværs af skolerne, er, at fremtidsværkstedet har været en effektiv metode til at facilitere vigtige dialoger om potentielle problemer og muligheder i læringsplatformen på måder, der har sikret meningsfuldt fokus og muliggjort reel kritik og inddragelse. Resultaterne peger endvidere på, at modellen med fremtidsværksteder og design-eksperimenter kunne være en måde at arbejde på skolerne i forhold til at fremme en eksperimenterende læringskultur, hvor it og læringsplatforme indgår forankrende i udvikling af nye didaktikker og samarbejdsformer på skolerne.

Med et citat fra Heino Apel i forhold til fremtidsværksteder: "The realisation of the realisation - who will support the group 'afterwards"' (Apel, 2004, s. 10 ) kan påpeges, at fremtidsværksteder og designworkshops i forbindelse med 
Læringsplatformsprojektet ikke bør blive en enkeltstående begivenhed, men at disse metoder netop har potentialerne til at indgå i et permanent forandrings- og udviklingsværksted på skolerne. Dette ligger indbygget i fremtidsværkstedsmetoden som en femte fase (se Jungk \& Müllert, 1984), men prioriteres sjældent. Men netop et nationalt storskala implementeringsprojekt som Læringsplatformsprojektet, der har potentiale til at udvikle sig som en fælles infrastruktur for læring, har krav på nogle metoder, som retter sig mod og inddrager alle.

Arbejdet med at integrere læringsplatformene er lige begyndt, så hvordan kan udviklingsarbejdet fortsætte? Og hvordan kan en tilgang med fremtidsværksteder og designworkshops skaleres op - dels i forhold kolleger på case-skolerne, som ikke havde mulighed for at deltage i Læringsplatformsprojektet, dels i forhold til øvrige skoler og dels i forhold til designere, platformsejere og øvrige aktørgrupper, således at videreudviklingen af MinUddannelse og de øvrige læringsplatforme kan blive et fælles projekt om en fortsat udvikling af folkeskolen? Resultaterne fra læringsplatformsprojektet, som også understøttes i den internationale forskningslitteratur (Tamborg, Bjerre, Albrechtsen, Andreasen \& Misfeldt, 2017) peger på, at brugerinddragelse er vejen at gå, når en organisation eller en hel sektor som her ønsker at udvikle ejerskab og kreativitet i forbindelse med ibrugtagning af teknologi. Det er således afgørende, at lærerne som de fagprofessionelle får en afgørende stemme i forhold til den aktuelle kamp om de teknologiske rammer, som udspiller sig i skolen.

\section{Tak}

Stor tak til det pædagogiske personale, lærere og leder fra caseskolen for at deltage i Læringsplatformsprojektet. De data, som ligger til grund for denne artikel, er indsamlet i samarbejde med Laura Lynggaard Nielsen fra Alexandra Instituttet og Linett Ræbild fra Aalborg Universitet. Linett Ræbild har endvidere forestået ASA-analyserne. 


\section{Referencer}

Apel, H. (2004). The Future Workshop. Deutsches Institut für Erwachsenenbildung. Lokaliseret den 19. oktober 2017 på: URL: http:// www. die-bonn.de/esp rid/dokumente/do c-2004/apelo4_o 2.pdf

Brown, T. \& Katz, B. (2009). Change by design: how design thinking transforms organizations and inspires innovation (1. udg). New York: Harper Business.

Bygholm, A. \& Nyvang, T. (2009). An Infrastructural Perspective on Implementing new Educational Technology: The Case of Human Centered Informatics. I L. Dirckinck-Holmfeld, C. Jones \& B. Lindström, Analysing Networked Learning Practices in Higher Education and Continuing Professional Development. Rotterdam: Sense Publishers.

Christensen, E. (2017): Aftale: Tusindvis af bindende mål bliver vejledende. Folkeskolen.dk. Lokaliseret den 7. november 2018 på: https://www. folkeskolen.dk/608308/aftale-tusindvis-af-bindende-maal-bliver-vejledende

Dirckinck-Holmfeld, L., Nielsen, L. \& Ræbild, L. (2016). Fremtidsvcerksted og design workshop. Aalborg \& Århus: Aalborg Universitet \& Alexandra Instituttet.

Dirckinck-Holmfeld, L. \& Ræbild, L. (2017). Delrapport 2: Fremtidsvcerksted, brugerindflydelse og ejerskab i brug af loeringsplatforme. Hentet på Styrelsen for IT og Lærings hjemmeside: https://www.emu.dk/modul/delrapport2-fremtidsv\%C3\%A6rksted-brugerindflydelse-og-ejerskab-i-brug-af1\%C3\%A6ringsplatforme.

Ehn, P. (1989). Work-oriented design of computer artifacts (2. udg.). Stockholm: Arbetslivcentrum.

Engeström, Y. (2001). Expansive Learning at Work: Toward an activity theoretical reconceptualization. Journal of Education and Work, 14(1), 133156. https://doi.org/10.1080/13639080020028747

Gynther, K. (2017). Delrapport 3: Designviden og -eksperimenter som afscet for brugerinddragende implementering af loeringsplatforme. Styrelsen for IT og Læring. Lokaliseret den 15. maj 2019 på: https://arkiv.emu.dk/ modul/delrapport-3-designviden-og-eksperimenter-som-afs\%C3\%A6tbrugerinddragende-implementering-af

Hansbøl, M. (2010). Researching relationships between ICTs and education: Suggestions for a science of movements. Århus: Danmarks Pædagogiske Universitetsskole, Aarhus Universitet.

Hoff, J. (2003): Informationsteknologiens demokratiske potentialer: Europæiske parlamentsmedlemmers holdninger til ny teknologi. I K. Lippert-Rasmussen, M. Gjerris, C. Emmeche, M. Hartlev, L. Koch, J. Hoff, \& G. Balling (red.), Der må voere en groense!: om holdninger til ny teknologi. København: Museum Tusculanum.

Jungk, R. \& Müllert, N. R. (1984). Håndbog ifremtidsvcerksteder. København: Politisk revy.

Kommunernes Landsforening. (2016). BRUGERPORTALSINITIATIVET KRAVSPECIFIKATION FOR LARINGSPLATFORM - VERSION 1.o. Lokaliseret den 1. november 2018 på: http://www.kl.dk/ImageVaultFiles/id_76010/ cf_202/BPI_Kravspecifikation_til_l-ringsplatform_version_.PDF

Kyng, M. \& Greenbaum, J. (red.). (1991). Design at work: cooperative design of computer systems. Hillsdale, NJ: L. Erlbaum Associates.

Leawitt, H. J. (1965). Applied organisational change in industry: Structural, technological and humanistic approaches. I J. G. March, Handbook of organizations. Chicago: Rand McNally. 
Misfeldt, M. (2016). Om projektet "Anvendelse af digitale loerings platforme og loeremidler". København: Styrelsen for IT og Læring.

Pinch, T. J. \& Bijker, W. E. (1984). The Social Construction of Facts and Artefacts: or How the Sociology of Science and the Sociology of Technology might Benefit Each Other. Social Studies of Science, 14(3), 399-441. https:// doi.org/10.1177/030631284014003004

Svensson, L. Ø., Tamborg, A., Misfeldt, M., Qvortrup, A., Kølsen, C. \& Gynther, K. (2017). "Anvendelse af digitale læringsplatforme og læremidler". Lokaliseret den 19. oktober 2017 på: https://www.emu.dk/sites/default/files/ Om\%2oprojektet_150517.pdf

Tamborg, A., Bjerre, A., Albrechtsen, T., Andreasen, L. B. \& Misfeldt, M. (2017). Delrapport 1: International forskningslitteratur om anvendelsen af digitale loeringsplatforme - et systematisk review. Styrelsen for IT og Læring. Lokaliseret den 15. oktober 2017 på: https://www.emu.dk/modul/ delrapport-1-international-forskningslitteratur-om-anvendelsen-afdigitale-l\% 3 \%A6ringsplatforme

Tamborg, A. (2017). Delrapport 5. Teknologianvendelse og interaktioner med eksisterende praksisser. Lokaliseret den 30. oktober 2017 på: http://www.emu.dk/modul/delrapport-5-teknologianvendelse-oginteraktioner-med-eksisterende-praksisser

Undervisningsministeriet [UVM] (2012): Gør en god skole bedre. Et fagligt løft affolkeskolen. Lokaliseret den 15. maj 2018 på: https://www.regeringen. $\mathrm{dk} /$ tidligere-publikationer/goer-en-god-skole-bedre-et-fagligt-loeft-affolkeskolen/ 
Learning Tech - Tidsskrift for læremidler, didaktik og teknologi Udgives af Læremiddel.dk

Learning Tech er et forskningstidsskrift, hvor alle artikler er forskerbedømt i form af dobbeltblindt peer review. Tidsskriftet bringer artikler, der rammer genstandsfeltet mellem læremidler, didaktik og teknologi, og hensigten er at spille en betydelig rolle som platform for den voksende skandinaviske læremiddelforskning.

\section{Redaktion}

Stig Toke Gissel, UCL Erhvervsakademi og Professionshøjskole (ansvarshavende redaktør)

Bettina Buch, Professionshøjskolen Absalon

Hildegunn Juulsgaard Johannesen, University College Syd

René Boyer Christiansen, Professionshøjskolen Absalon

Stine Reinholdt Hansen, UCL Erhvervsakademi og Professionshøjskole

Thomas R.S. Albrechtsen, University College Syd

\section{Redaktionssekretær}

Trine Ellegaard, UCL Erhvervsakademi og Professionshøjskole

\section{Temaredaktion}

Ane Qvortrup, Syddansk Universitet

Stig Toke Gissel, UCL Erhvervsakademi og Professionshøjskole

Morten Misfeldt, Aalborg Universitet

Jens Jørgen Hansen, Syddansk Universitet

\section{Design og grafisk tilrettelæggelse}

Trefold - grafisk design og kommunikation

\section{Tryk}

Narayana Press, Gylling

ISSN 2445-7981 (Tryk)

ISSN 2445-6810 (Online)

\section{Rettigheder}

(C) 2019 Læremiddel.dk og forfatterne

\section{Kontakt}

Læremiddel.dk, Niels Bohrs Allé 1, 5230 Odense M

https://learningtech.laeremiddel.dk

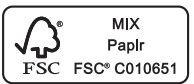

